\title{
Plural Processes, Patterned Connections
}

\section{SPIKE PETERSON}

Department of Political Science, University of Arizona

\begin{abstract}
Plural globalizations refer to large-scale processes occurring today at an accelerated pace (due to information and communication technologies) and with extremely uneven effects (due to continuing and new inequalities). Conventional analytical and disciplinary frameworks can neither make adequate sense of, nor effectively politicize, these developments. The quantitatively large scales and qualitatively novel changes require new orientations. This essay draws on critical, interpretive, feminist perspectives to propose conceptual innovations and a cross-disciplinary framework for analyzing globalizations. The alternative framing moves beyond a narrow definition of economics to identify and integrate reproductive, productive, and virtual economies (understood in a Foucauldian sense as systemic sites through and across which power opcratcs). The new framing brings the concepts and practices of "social reproduction", non-wage labor, and informalization into relation with the familiar but increasingly global, flexibilized, and service-oriented "productive economy", as well as with the less familiar but increasingly consequential "virtual economy" of financial markets, commodified information, and the exchange less of goods than of signs.
\end{abstract}

\section{Introduction}

As a starting point, I understand globalizations as large-scale processes occurring today at an accelerated pace (due to information and communication technologies) and with extremely uneven effects (due to continuing and new inequalities). We cannot make sense of globalizations through conventional analytical and disciplinary frameworks. ${ }^{1}$ The quantitatively large scales and qualitatively novel changes require new orientations. As Tomlinson (1999, p. 17) writes: 'The sheer scale and complexity of ... global connectivity is ... something we can only grasp by cutting into it in various ways'.

The 'cut' I pursue in this essay reflects my commitment to politicizing the uneven effects of globalizations. I believe that this is an urgent though daunting task and one that is appropriate to

Correspondence address: V. Spike Peterson, Department of Political Science, University of Arizona, USA. Email: spikep@email.arizona.edu 
the new journal, Globalizations. The substance of the essay draws from my recent book, A Critical Rewriting of Global Political Economy: Integrating Reproductive, Productive and Virtual Economies (2003). I first describe the motivations for and nature of the book, and introduce its analytical innovations. The latter enable more inclusive and integrative ways of 'seeing' multiple globalizations and making critical sense of their implications. The remainder of the essay draws on the book's theoretical framing and empirical data to describe plural processes and patterned connections. The schematic presentation in this reduced space necessarily favors major trends and patterns over the complexity of lived processes. I hope nonetheless that revealing key features of 'what is going on' can productively inform both our analytical comprehension of globalizations and political resistance to their oppressive effects. I also hope to demonstrate the value of feminist, postcolonial and interpretive lenses.

\section{A Critical Project}

A Critical Rewriting of Global Political Economy moves beyond a narrow definition of economics to develop an alternative analytical framing of reproductive, productive and virtual economies. $^{2}$ Through a cross-disciplinary lens, the book attempts to rewrite global political economy (GPE) by demonstrating the interdependence of these economies, and to advance critical theory by illuminating the intersection of race, gender and economic inequalities (within and among states) as structural features of global processes. If in one sense the book offers a systematic description and critical analysis of globalization understood as economic restructuring (neoliberalism), in an additional and more provocative sense, the description and analysis themselves expose the centrality of culture (epitomized by symbols, socialization and the virtual economy) to our understanding of GPE.

On the one hand, I argue that a more expansive 'RPV framing' is necessary to address two globalization trends that affect everyday lives worldwide. The first is explosive growth in financial markets that shapes business decision making and public policy making. The second is dramatic growth in informal and flexible work arrangements that shapes income-generation and family well-being. While these developments are widely recognized, they are rarely analyzed in relation-as interdependent phenomena. In contrast, the RPV framing provides a way to see informal activities, flexibilization, global production, migration flows, capital movements and virtual activities as interacting dimensions of plural global processes.

On the other hand, I argue that prevailing accounts of globalizations are analytically inadequate and politically problematic. I refer particularly to the dominant accounts of economic restructuring generated primarily by mainstream scholars in the disciplines of economics and international relations. I join other critics in arguing that the orthodox orientations of both disciplines are compromised by particular conceptual and methodological commitments. In brief, their economistic, modernist and masculinist starting points ${ }^{3}$ preclude adequate analyses of two additional features of global restructuring.

First, today's globalizations are distinguished by their dependence on information and communication technologies specific to the late twentieth century. ${ }^{4}$ These technologies not only enable the 'global' in globalizations but transform the world as we 'know' it. The point here is that globalizations involve not only empirically observable changes in speed, scale and scope, but also analytical challenges posed by information technologies and their unprecedented fusion of culture and economy - of virtual and material dimensions. In fundamental ways, these technologies feature non-material components as decisive, and further the production of dematerialized and intangible goods: services, ideas, information and 'symbolic' money. 
Making sense of these developments entails analytical lenses appropriate for interpreting the symbolic, cultural and virtual. Hence, my interpretive/postmodernist orientation.

Second, even as these technologies enhance integration and homogenization, globalizations and their effects are extremely uneven-manifested starkly in interacting stratifications of ethnicity/race, class, gender and nation. Advocates of globalization avoid theorizing the nature and role of oppression in relation to neoliberal policies. Critics tend to focus on one or another of these hierarchies, or at best 'add' one to another. The point here is that theoretical attention to hierarchies as a structural feature of globalization, and especially their interconnections, remains underdeveloped. Hence, my critical, postcolonial, feminist orientation.

As a contribution to theorizing the intersection of global hierarchies, I deploy gender analytically: as a governing code that privileges that which is characterized as masculine (not only men) at the expense of that which is characterized as feminine (not only women but subjects and practices stigmatized as lacking agency, skills, control, reason or power). The claim here is that gender-and its denigration of the feminine-pervades language and culture, with systemic effects on how we take for granted (effectively naturalize) the devaluation of all feminized identities and activities. Hence, stigmatizing work and workers as 'feminine' devalorizes women but also racially, culturally and economically marginalized men and thus links devalorized work and workers (women, migrants, the underclass of cities and developing countries).

In short, I argue that mainstream and even critical theories of globalizations and GPE are partial and problematic. We need new 'ways of seeing' and theorizing that not only accommodate new developments but also cultivate the identification of relationships among plural processes of globalization. To contribute to such rethinking, I introduce two conceptual

innovations: the 'RPV framing' (of reproductive, productive and virtual economies) and what I refer to as 'triad analytics'.

\section{Relational Framing}

In essence, the RPV framing brings the conceptual and material dimensions of 'social reproduction', non-wage labor and informalization into relation with the familiar but increasingly global, flexibilized, information-based and service-oriented 'productive economy', as well as with the less familiar but increasingly consequential 'virtual economy' of financial markets, commodified knowledge and the exchange less of goods than of cultural codes. Including the reproductive economy invites attention to otherwise marginalized agents and activities, and acknowledges especially the importance of gender-sensitive research and analysis. Including the virtual economy addresses developments in 'symbolic money', informationalism and the commodification of intangibles and aesthetics. It acknowledges the importance of interpretive approaches for analyzing how symbols and expectations mediate our constructions of 'value'.

The RPV framing directs our attention to more features of globalizations and illuminates linkages and relationships across an expanded-and shifting-terrain. Rather than offering an explanatory theory, the framing facilitates shifts in how we see the terrain and hence how we might understand and respond to it. It is one of many analytical 'moves' needed for studying globalizations.

The specification of multiple and interactive economies illuminates and politicizes patterns, a critical assessment of which can inform proactive strategies. At the same time, the framing effectively increases awareness of the need for plural strategies informed by local realities. The complexity and fluidity of globalizations argue against a single logic of analysis or univocal social movement in pursuit of a more equitable world order. Both analysis and struggle are more 
complex than conventional (positivist and modernist) approaches encourage us to appreciate. The RPV framing is an attempt to acknowledge this complexity while making sense of it, and to politicize neoliberal globalization by exposing the sense that it makes.

While the RPV framing is more specific to rewriting GPE, a second analytical innovation, 'triad analytics', is applicable to social relations more generally. The positivist/modernist dichotomies of conventional social science tend to obscure relations of interdependence and embeddedness and to marginalize issues of identity and subjectivity. To facilitate a shift from the binary tendencies of conventional framing, my triad analytics posits identities (subjectivity, self-formation), meaning systems (symbols, discourse, ideologies), and social practices/institutions (actions, social structures) as co-constituting dimensions of social reality. These are of course inseparable in practice, but analytically specifying their interaction affords additional 'order' for systematic investigation of globalizations. Stated simply, the triad insists on fully integrating 'who we are', 'how we think' and 'what we do'.

On the one hand, this framing invokes familiar categories: concrete practices/institutions (actions, social structures, politics, economics, etc.) and conceptual 'abstractions' (symbols, concepts, discourse, ideology, etc.). On the other hand, it insists on complicating this familiar juxtaposition in two crucial, even transformative, ways. First, it moves away from dichotomized constructions (e.g. material-symbolic, structural-discursive, empirical-analytical) that encumber conventional theorizing and divide academic disciplines. It rejects oppositional framing in favor of understanding the material and symbolic relationally, that is, as interactive and co-determining dimensions of social reality. Second, triad analytics insists that social practices and conceptual habits are equally inextricable from identification processes and their politics: all three dimensions are mutually constituted, hence interactive, dynamic and historically contingent. This draws our attention to issues of subjectivity, sexuality and self-formation as well as the social hierarchies and 'micro-power' that structure identity formation and ideological preferences. These are issues that have been too long neglected, even excluded, from mainstream analyses in the social sciences.

Neoliberalism is typically cast as economic restructuring in the 'north' and structural adjustment policies (SAPs) in the 'south'. Briefly, the market reforms promoted by neoliberalism include liberalization (to open borders to the flow of goods and capital), deregulation (to remove existing state restraints), privatization (to replace the 'inefficiencies' of public ownership and control), and stabilization policies (to reduce government spending, deficits and aggregate demand). Finally, specialization in economic activities is promoted, based on the assumption of comparative advantage, and export-oriented policies are favored in pursuit of economic development and growth (Berik, 1999, pp. 402-409; Bakker, 1994a, pp. 7-17). Neoliberal policies appear to weaken state power and do erode the state's provision of public welfare. Critics argue that neoliberal discourse obscures the state's continued, even strengthened, role in sustaining the rights and power of private capital. In effect, global processes are not so much 'deregulated' but reregulated by market—rather than socially accountable, state/government-forces.

\section{The Productive Economy}

Of the three economies, I begin with the productive economy (PE) because its identities, ideologies, practices and institutional manifestations are the most familiar and because it is central to globalizations-particularly when understood in the register of economic restructuring and its power relations. Indeed, the meaning, location and value of 'work' - that activity so central to individual and family well-being - are associated almost exclusively (though mistakenly) 
with the PE. The latter is conventionally understood as the sphere of formal (contractual, regulated) exchanges, with production differentiated among three sectors: primary (natural resources), secondary (manufactures) and tertiary (services). Here I can address only the major trends as globalizing processes transform these production relations; each has implications for the practices, identities and valorization of workers.

\section{Decline in Primary Production}

The last three decades have witnessed a dramatic decline in world prices of and demand for (non-oil) primary products and raw materials. The decreasing value of primary commodities-which earlier constituted the growth sector of industrializing countries-is contrasted with increasing prices of manufactured and high-value added commodities characteristic of advanced economies. Technologies figure prominently here: improving food production and productivity and decreasing demand for (non-oil) raw materials in favor of high-technology and knowledge-intensive industries. Food supplies and manufacturing production remain important, but they depend on fewer and different inputs. These changes are especially damaging to developing economies, where primary production dominates: ${ }^{5}$ unemployment problems are exacerbated, the ability to attract foreign investment is reduced, and debt dependence may be increased (Hoogvelt, 2001). These countries may then view (unregulated) labor as their most competitive resource and/or witness out-migration in search of work.

\section{'De-industrialization'}

A second pattern, 'de-industrialization' encompasses two trends. Increased manufacturing productivity creates 'jobless growth', and the job growth that occurs is primarily in hightechnology and information-based manufacturing (products that are also services). In a second sense, manufacturing is 'downgraded' by the loss of skilled and often unionized positions and dramatic growth in low wage, semi-skilled and unskilled jobs. ${ }^{6}$ These trends are most prominent in advanced economies and major cities. In developing countries, state-directed domestic industrialization and the jobs it provided (primarily for urban men) have lost out to 'privatized' export enclaves.

\section{Growth in and Globalization of Services}

The most significant job growth is in services, which constitute employment for $50-70 \%$ of the workforce in advanced economies, and the percentage is increasing in developing countries as well (World Bank, 2000, p. 29). Two processes interact: employment shifts from manufacturing to information-based services, and growth in and the nature of the service economy renders it the 'dynamic base from which manufacturing developments may derive' (Lash and Urry, 1994, p. 213). Hence, manufacturing and services are hardly separable, and the PE more generally is increasingly 'information soaked'.

De-industrialization and growth in services are associated with income polarization and a 'declining middle'. ${ }^{8}$ In contrast to Fordist manufacturing jobs and unionized workers, service jobs tend to be either skilled and high-waged (professional-managerial jobs in health, education, financial, and legal services) or semi-skilled, unskilled and poorly paid (in cleaning, food, retail and telemarketing services). Institutionalized patterns here repeat themselves: differential access to education, training and career opportunities are structured by gender, race, class, and national 
location so that the polarization typical of services is patterned by familiar hierarchies (Mohanty, 2003; Marchand and Runyan, 2000).

Uneven access to capital-featured in the VE-tends to exacerbate these patterns as foreign direct investment (FDI) flows are subject to sectoral and geopolitical shifts. First, from a concentration in the primary sector until the 1950s, FDI shifted to manufacturing (45.2\% in 1970) and then services (53.6\% in 1994) (Castells, 2000, p. 120). In 1997, service industries accounted for approximately two-thirds of global FDI (World Bank, 2000, p. 72). This shift is also linked to the VE in so far as it reflects a reorientation of investment strategies-from long-term 'productivist' strategies (associated with industrial manufacturing) to 'short-term' strategies associated with trade in services and global financial markets.

Second, most FDI is highly concentrated in advanced economies. The percentage to all developing countries has been declining since 1997, fell to 17\% in 2000 (United Nations, 2001, p. 45), and continued to decline through 2002 (United Nations, 2003, p. 26). Of the FDI going to developing economies, most goes to a few large countries (China, Brazil, Mexico) leaving others with little or no access to this capital. For instance, the African continent received less than $2 \%$ of the world total of foreign investment in 1997 (World Bank, 2000, p. 72), and less than 1\% in 2000 (UN, 2002, p. 12). In effect, more than half of all developing countries are marginalized from the presumed benefits of FDI: credit, infrastructural development and technology transfer. Lack of capital has immediate and long-term effects, especially in an informational age, where valued labor and value-added production requires a skilled workforce-requiring in turn long-term investments in education and infrastructural development.

\section{Flexibilization as Feminization}

Flexibilization is the buzzword of neoliberal restructuring. Less frequently acclaimed is its feminization (deterioration) of working conditions. ${ }^{9}$ I understand feminized flexibilization as simultaneously a material, embodied transformation of labor markets, a conceptual characterization of devalorized labor conditions, and a reconfiguration of worker identities.

First, as an increasing proportion of jobs require few skills, the most desirable workers are those who are perceived to be undemanding (unorganized), docile but reliable, available for part-time and temporary work, and willing to accept low wages. Prevailing conceptual codes depict women as more attractive candidates for these jobs (Mohanty, 1997, p. 20). Prevailing gender realities are that women-in spite of decades of activism and legal advances-continue to earn 30-40\% less than men worldwide (DAW, 1999). Hence, the expectation and reality that women can be paid less than men for similar work. And in spite of heading almost one-third of the world's households (Chant, 1997), women are still thought of as secondary earners, not primary (read male) breadwinners. This assumption is used-intentionally and otherwise-to 'justify' lower wages for women, as if their earnings were marginal to family well-being and the 'real' economy of men's work.

A second dimension is the real and perceived flexibility of women as workers: women have had little choice about learning to be flexible given the erratic, complex and unpredictable scheduling of reproductive labor. A corollary stereotype and sometimes reality, is that flexibilized work arrangements are therefore attractive to-and 'good for'-women, enabling them to earn income while also fulfilling domestic responsibilities.

Third, women constitute an increasing percentage of the formal workforce: since the 1980s especially, their proportion has been increasing worldwide, while male participation has been falling (Standing, 1999, p. 588; UN/Women, 2000, 110). Fourth, life-cycles and demographic 
patterns are changing: women are staying in the labor force longer, delaying maternity and decreasing the number of children they have, working throughout their reproductive years, and increasingly subsidizing family/household income (Wichterich, 2000; UN/Women, 2000; United Nations Development Program (UNDP), 1999, p. 27).

In sum, feminization of the workforce refers to both women's increased share of paid employment and 'a transformation of the conditions of paid work, such that more jobs are casual, irregular, flexible and precarious, characteristics that hitherto were more typical of "women's work" than of "men's work"” (Grown et al., 2000a, p. 1147; also Standing, 1999, p. 583).

\section{Flexibilization in Relation to Migration, Gender and Racialization}

Globalizations are increasingly about people on the move: to urban areas, export processing zones, seasonal agricultural sites and tourism locales. The central point here is 'migrations do not just happen' (Sassen, 1998, p. 58); they are shaped by colonial histories, geopolitics, state policies, capital flows, labor markets, cultural stereotypes, skill attributions, kinship networks and identity markers. Consistent with structural vulnerabilities and the nature of 'unskilled' jobs most frequently available (cleaning, harvesting, domestic service, sex work), it is no surprise that migrant worker populations are especially marked by gender and race/ethnicity (e.g. Sassen, 1998; Young, 2001). Moreover, being on the move-for work, recreation or escape-affects personal and collective identities and cultural reproduction. Not least, traditional family forms and divisions of labor are disrupted, destabilizing men's and women's identities and gender relations more generally. Shifting identities have complex effects on imagined communities, whether expressed in anti-immigrant racism, nationalist state building, ethno-cultural diasporas, ethnic cleansing or patriarchal religious fundamentalisms. In so far as collective identities have historically been linked to 'place', these shifting places pose new identity questions. ${ }^{10}$

Flexibilization benefits some more than others. It tends to increase the power and autonomy of management and be attractive to those with highly valued skills. Mothers and single parents may also find flexible arrangements better suit their life conditions, although this must be assessed in the context of available childcare arrangements and limited access to better-paying and more secure employment opportunities (Wichterich, 2000). While the trade-offs will obviously depend on specific contexts, the general point remains: in the absence of regulatory frameworks that protect workers' rights and generate living wages, flexibilization translates into greater insecurity of employment, income and benefits for the majority of workers.

Flexibilization is displacing 'regular' employment worldwide. Mies (1998) genders this trend by calling it 'housewifization': where male workers who expected otherwise now find themselves in the situation of housewives-atomized, unorganized and economically insecure. This trend is also - and inextricably_raced, classed and nationalized because devalorized labor is undertaken primarily by women as well as racially marginalized men, migrant workers and immigrants.

\section{The Reproductive Economy}

Unlike the PE, the reproductive economy (RE) is rarely analyzed in mainstream accounts. ${ }^{11}$ This neglect is due in part to conceptual habits: locating men in the public sphere of power and 'real'-that is, paid-work, and women in the family/private sphere of emotional maintenance, leisure and caring - that is, unpaid-labor. It is also due to institutionalized practices: for 
example, academic disciplines that study social life as separate (psychological, family/social, economic, political) spheres of inquiry. I argue, in contrast, that what are regarded as 'informal' activities in the RE are crucial for analyzing economic relations and even globalizations. Here I focus on three reasons for not only including but even foregrounding the RE: the significance of socialization, the devalorization of 'women's work' and increasing informalization.

\section{Socialization}

Socialization is about learning how to be human according to the codes of a particular cultural environment. Family life is where we first observe and internalize gender differences, their respective identities and divisions of labor. This acculturation is inextricable from patterned beliefs about race/ethnicity, age, class, religion and other axes of 'difference'. And what we learn at an early age is psycho-socially formative: the 'ordering' (language, cultural rules, ideologies) we acritically imbibe in childhood is especially resistant to transformation. Socialization is thus central to analyses of continuity and change.

Socialization also matters structurally in two vital ways. It produces human beings who are then able to 'work' and saves capital from having to 'pay' for this production of labor inputs. And it instills attitudes, identities and meaning systems which enable societies to function. Capitalism, for instance, requires not only that 'workers' accept and perform their role in 'production', but that individuals more generally accept hierarchical divisions of labor and their corollary: differential valorization of who does what kind of work.

\section{Women's Work}

Socialization and the caring labor required to sustain family relations are stereotyped as 'women's work' worldwide. Yet in spite of romanticized motherhood and a glut of profamily rhetoric, neoliberal globalization reduces the emotional, cultural and material resources necessary for the well-being of women and families.

The traditional ideology of patriarchal states, religions and families locates women in the privacy of the home as loyal dependents and caring service providers who sustain family life with emotional, sensual and material labor and, when necessary (or culturally desirable), supplemental earnings. These ideologies also constitute identities. In particular, women are expected to be more selfless than men and to serve the family first, as caring laborers and moral guardians; men are expected to be the primary income earners (the 'breadwinners'), to represent family interests, and to serve both their own and their family's interests. Because women are economically more vulnerable, have fewer valued skills, and are socialized to put families first, they are less able to avoid devalorized work, especially when household incomes decline.

These ideologies are deeply rooted historically and structurally, and profoundly shape how the bodies, desires, knowledge, skills, experience and activities of women and men are differentially valorized. In particular, the work that women do is devalued (both materially and ideologically), and women have fewer legal protections than men do, fewer property rights and less access to education, training and work opportunities that are associated with highly valued skills. In short, women - and especially women who are racially and economically disadvantaged - have very limited options for generating income. Yet women are held responsible for ensuring their own and their family's well-being under deteriorating economic conditions. As families worldwide confront shrinking economic resources, women are disproportionately expected to 
compensate - to absorb the costs of 'adjustment'. Sassen calls this the 'feminization of survival' (2000) and as a survival strategy, women especially rely on informal activities to ensure social reproduction.

\section{Informalization}

Global processes interact to increase dramatically the volume, value, extent and socio-political significance of informal sector activities. The shadow or underground economy was in 1998 estimated to be $\$ 9$ trillion - the equivalent of approximately a quarter of the world's gross domestic product for that year (The Economist, 28 August 1999, p. 59). Yet these figures do not even begin to account for 'women's work'. Including this reproductive labor transforms measures of 'economic production', adding $1 / 4$ to $1 / 3$ to the world's gross national product (Sivard, 1995, p. 11). ${ }^{12}$

Globalizations more generally, and neoliberal restructuring specifically, constitute the context of growth in informal activities. Decisive here are global circuits of production and people (treated in the PE) and flows of capital. The latter are fueled by deregulation and pursuit of higher profits by cutting costs and enhancing investment returns. They are also a function of geopolitical debtor and creditor dynamics, patterns of foreign direct investment, and government strategies for securing 'hard' currency through increasing dependence on remittances. ${ }^{13}$

Informalization is heterogeneous and controversial. Some individuals prosper by engaging in entrepreneurial activities-licit and illicit—afforded by a less regulated environment. This is especially evident in developing countries, where informal activities are crucial for income generation, in micro-enterprises favored by neoliberals, and in the explosive growth in criminal activities worldwide. ${ }^{14}$ Informalization thus poses fundamental questions regarding globalizations in relation to family livelihoods, work conditions, what counts as economic activity and how activities are valued. It effectively forces us to revise our theories of political economy. ${ }^{15}$ Yet for the most part, mainstream accounts continue to neglect how social reproduction is crucial to, and inextricable from, activities in both informal and formal sectors. And they certainly neglect how informal activities shape, and are shaped by, the intersections of race, gender, class and national location.

Feminists, in contrast, have for long studied domestic or reproductive labor to analyze the relationship between unpaid work in the home and income generation, formally and informally. They argue that work in the RE produces labor power (workers) and social infrastructure upon which the formal economy depends. As already noted, this 'free' (unpaid) labor benefits employers, who do not then have to pay the full costs of producing the labor force. Similarly, it hurts workers in the formal economy by placing downward pressure on wage demands (insofar as employers are not 'expected' to pay for social reproduction). That is, reproductive labor is key not only for production of workers but also for determining wages in the formal/ productive economy; wage levels in turn affect resources available to families and shape the nature and extent of informal activities in support of family/household maintenance.

In sum, women-especially those disadvantaged economically, racially and geopoliticallyare increasingly the backbone of globalizations (Wichterich, 2000; Dickinson and Schaeffer, 2001). They are doing more work because capital draws them into the formal economy as the cheapest workers. They are the cheapest workers because patriarchal and racist ideologies devalue feminized bodies, skills and labor, limit women's access to valorized skills and resources, and thereby constrain the choices available for work outside stereotypical roles for women (and feminized 'others'). Capital takes advantage of existing structural hierarchiesand the ideologies and identities that reproduce them-by presupposing the reproductive 
labor of women, channeling feminized workers into insecure, low-paying services and laborintensive employment, and promoting informalization and flexibilization (which are enabled by state complicity in deregulation). Informalization depresses formal wages and effectively disciplines all workers. The increase in women's labor, and that of other vulnerable groups, serves the structural interests of capital by securing higher profits, inhibiting collective organization (through the isolation of workers), and obscuring structural contradictions (by 'taking up the slack' while leaving capitalist/patriarchal principles intact), thus frustrating systemic analyses and potentially more effective resistances. Patriarchal ideologies interact with racism (which is inextricable from national hierarchies and migration from low- to high-income countries) to render women, the poor, migrants and recent immigrants the prototypical workers of the informal/flexibilized economy and arguably the future of all but elite workers worldwide.

\section{The Virtual Economy in three modes, or VE1, VE2 and VE3}

As so many have noted, globalizations are especially visible in flows of information, symbols, and communication through electronic and wireless transmissions that defy territorial constraints. We must acknowledge and address both the new scale and velocity of these transmissions and the different (symbolic, non-material, virtual) nature of these processes and their unique effects. Because symbols are intangible, they are not subject to time and space or the conventional analyses of material goods. Symbols are inherently cultural and their circulation fuses culture and economy in novel ways. This disrupts conventional binaries and habitual modes of analysis and requires interpretive or postmodern approaches that take cultural coding seriously. In short, we are forced to rethink not just the nature of symbolic or virtual 'goods' themselves but also how processes of thinking, knowing, producing, marketing, consuming and valorizing are being reconstituted.

Specifying the virtual economy permits us to examine this unfamiliar but increasingly consequential terrain. I distinguish three (overlapping) modes of the virtual economy: the exchange of symbolic money in the context of global financial markets, of information in the context of a 'post-industrial', 'informational' or 'service economy', and of cultural symbols in the context of postmodern aesthetics, consumption, meaning and culture.

\section{Global Financial Markets, or VE1}

Since the 1970s floating exchange rates, reduced capital controls, offshore transactions, desegmentation, new financial instruments, securitization and the rise of institutional investors have interacted to amplify the speed, scale and complexity of financial transactions. Powerful states have been complicit in, and technologies have been decisive for, enabling the mobility of capital and its enhanced power. The result is an "enormous mass of "world money" ... [that] [that] is not being created by economic activity like investment, production, consumption, or trade ... It is virtual rather than real [commodity] money' (Drucker, 1997, p. 162).

The point is not that this 'delinking' insulates the real economy from global finance, because prices 'set' in the virtual economy (through interest and exchange rates) have decisive effects throughout the socio-economic 'system': they shape investments (short- or long-term; in trade, financial instruments or human resources), the production of goods and services (material based or knowledge based; labor intensive or capital and technology intensive) and the structure of labor markets (what types of labor, where located, with what compensation and under what conditions). But symbolic/credit money is also differently constituted than commodity money; 
it cannot be reduced to money's conventional 'function of a "lubricant" within a pre-existing monetary order' (Thrift, 1996, p. 217). In particular, the symbolic/informational content of money is not neutral but continually open to interpretation, and that interpretation depends less on objective indicators than on subjective ideas, identities and expectations.

Consequences are multiple. Most visible are the risks of financial crises and their extensive effects. ${ }^{16}$ Within firms and organizations, an increasing urgency in regard to 'managing money' shifts attention, jobs and status to the financial officers or departments of corporation and organizations. Within the state, power shifts from legislative to executive branches and agencies that oversee financial planning. Within domestic economies, labor markets are reshuffled to accommodate shifting production and investment strategies. As one corollary, the provision of social welfare is ideologically constructed as a 'luxury' that viable national economies cannot afford, while corporate welfare is typically enhanced as a 'necessary' aspect of improving national competitiveness. At the global level, financial decision making power is concentrated in firms and organizations with ambiguous relationships to public accountability. The implications for democratic process and more equitable distributions of global wealth are matters of urgent concern (e.g. Mittelman, 1996; Gill, 1997b; Kelly et al., 2001).

\section{The Informational Economy, or VE2}

This mode of the virtual economy features the exchange of knowledge, information or 'intellectual capital' (Dunning, 2000, p. 8). While all processes involve informational/knowledge content, the VE2 permits us to examine information as the commodity: ideas, codes, concepts, knowledge are what is being exchanged. Information is inherently conceptual and hence cultural; its commodification thus entails a fusion of economy and culture that disrupts conventional economic analyses. We cannot just 'add' informational goods to existing theories, as if the number of commodities in circulation has simply increased. ${ }^{17}$ Rather, the cultural 'substance' of informational goods entails both changes in thinking about production and exchange, etc., and more complex metamorphoses in thinking itself. The claim here is that the informational economy necessarily involves a transformation not only of goods but also of minds, thinking and cultural codes.

Technologies are again central. Computer-based digitization enables the conversion (reduction) of information, images, literature, music and even human experience into a binary code of $1 \mathrm{~s}$ and 0 s available to anyone with the relevant 'reading' capacity (conceptual and technological). Not only are these many and diverse phenomena reduced to a common, universal, code but in coded form they are available around the world, virtually without the constraints of time and space. Digitization also effectively 'objectifies' these diverse phenomena, rendering them objects/commodities that are tradable. The benefits are multiple and well rehearsed. Here I note more troubling aspects that warrant our attention.

Not all information/knowledge is deemed worthy of digitization or incorporation in networks of communication. The selection of what is included and to what effect is inherently a political one, informed by the cultural preferences and political-economic interests of those with greater ownership and control of relevant media. Similarly, access to and control over 'valued' informational goods, training and technologies is structured by familiar patterned exclusions. Finally, how do we interpret and evaluate the effects of this 'objectification' and 'commodification' of the life world, where the 'value' of any information, product or experience is increasingly subject to determination by transnational market forces? This is especially 
difficult in regard to the realms of intimacy, bodies, privacy and spirituality, as the logic of profitmaking subsumes all that is commodifiable within it.

The fluid, dynamic and transformative aspects of the VE2 make it and its power relations difficult to map, not least because they involve more subjective assessments of value, credibility and authority than objective assessments of volume or quality. Yet we can ill afford to neglect these developments and their cultural codings as we attempt to make sense of globalizations.

\section{The Consumer Society as an Economy of Signs, or VE3}

The third mode of the virtual economy features the exchange of aesthetic or cultural signs/ symbols. I focus here on heightened consumerism involving the creation of a social imaginary of particular tastes and desires and the extensive commodification of tastes, pleasure and leisure. Aesthetics and cultural symbols figure prominently here. The consumer economy emphasizes not the material aspects of objects exchanged but the signs, symbols and codes that invest these commodities with (cultural) meaning and value. In an important sense, capital focuses less on producing consumer goods than on producing consumer subjectivities and a totalizing 'market culture' that sustain consumption.

Cultural coding, of course, is an aspect of all production and consumption. It assumes a new significance, however, as commodification penetrates all aspects of culture and the production of desire and rapidly changing tastes are key to surplus accumulation. Amin (1994) identifies two aspects of this consumerizing process. The 'aestheticization of commodities' fuses economic and cultural activity by 'enlivening everyday life at the same time as legitimating consumerism and social acceptance of the imperatives of capitalism'. The 'commodification of aesthetics' transforms culture and cultural activity 'into cultural industries, that is, commodities sold in the market', thereby encouraging consumers to 'increasingly identify cultural gratification with consumption', rather than other perhaps more meaningful and less profit-oriented activities (Amin, 1994, p. 31; citing Urry, 1990).

While affluent consumption is the privilege of only a small percentage of the world's population, it shapes the choices (and valorization) of those without affluence. ${ }^{18}$ In short, there is a political economy of consumption, with pervasive but extremely uneven effects. First and foremost are the effects of consumerism as an ideology that becomes 'common sense'. Even where goods or the resources to buy them are not available, the desire for them is fueled by pervasive advertising and global media. The problematic core assumption is that self- and social-expression are primarily achieved through the consumption of goods. Similarly, (private) consumption threatens to displace traditional (public) forms of political activity and identification.

Second is the power-laden issue of practicing consumption. Whose needs, desires and interests are served? Whose bodies and environments are devalorized in pursuit of consumerism and the neoliberal commitment to growth (rather than redistribution) that fuels it? Third, consumerism requires purchasing power. Involving assessment of risks and reliability, mediated by computer surveillance and access, credit features prominently in the distribution of present and future resources. Patterns regarding who has it, how much they have, and how they use it correspond tellingly to gender, race/ethnicity, class, and geopolitical stratifications.

Consumption is linked to the RE because households have been traditional sites of consumption, families are important sites of socialization into 'appropriate' cultural codes (involving desires, identities, lifestyles), and informalization reshapes consumption patterns (altering divisions of labor and resources; generating goods outside the 'regular' economy). Consumption is 
linked to the productive economy because flexibilization furthers the creation of niche markets and a consumer aesthetic premised on rapid turnover in design, fashion and tastes. These production processes are inextricable from newly mobile capital, new divisions of labor and new identity patterns.

\section{Conclusion}

I have argued that prevailing orientations are incapable of addressing the multiple scales, complex connections and plural processes of globalizations. The necessarily abbreviated account in preceding sections had two objectives: to offer a schematic mapping of major trends and their implications, and to demonstrate the value of more inclusive analytical framing. To accommodate space constraints, I have focused primarily on economic restructuring as a pervasive and especially powerful dimension of globalizations. I argue, however, that the analytical innovations deployed herein have relevance beyond conventional notions of 'political economy'. In particular, the RPV framing and triad analytics enable a relational orientation that takes seriously the power dynamics, structural processes and material effects of 'economics' while revealing their embeddedness in symbolic/cultural systems and the subjectivities, ideologies and values they encode. As one way to illustrate the relevance of a relational orientation to social relations-and globalizations-more generally, I conclude by indicating suggestive linkages between the two least familiar economies: the RE and the VE.

First, socialization in the family/household involves psychological processes, subject formation and collective acculturation. It is key to the reproduction of identities and ideologies that deeply shape our behaviors and tend to naturalize structural hierarchies. Socialization also generates attitudes regarding competition, risk, trust, short-term versus long-term expectations of reward and, ultimately, investment orientations that are key to activities in the virtual economy. Features of the RE are thus central to analyzing a variety of social relations. At the same time, globalizations are changing social relations and conditions of social reproduction. Attention to the RE alerts us to how, for example, sexual politics, reproductive technologies, increasing female employment and expanding informalization are destabilizing heteronormative family forms, patriarchal households, purchasing patterns and familiar divisions of labor.

Second, the RE and VE are linked-as all socio-economic and political decision making is linked-by the relationship between necessarily value-laden individual preferences and the reproduction (and transformation) of systemic determinations of value. In other words, our individual decision making is systemically shaped by, and shapes, the value attributed to money (a virtual economy effect), how money is generated through informal and formal work (aspects of the reproductive and productive economies), and how money is spent (in all the economies) via consumption. The differential valorization of work and workers is key to inequitable distributions of resources and power, including the power to determine whose analytical and cultural codes dominate. This opens the inquiry to operations of power in, for example, global media, arts and entertainment, leisure activities, tourism and knowledge-producing institutions.

Third and more conventionally, the family/household is a key site of accumulation, production, consumption and investment, and these processes variously shape, and are shaped by, macro-level phenomena. For example, household savings and investment strategies are influenced by monetary policies that establish interest rates, but household strategies also affectthrough savings, consumption, investment, and political activities-the economic decision making that determines monetary policy. ${ }^{19}$ As Castells and Portes (1989, p. 6) put it, 'research 
on [reproductive and informal] activities thus affords a unique glimpse into the ways in which individual strategies connect with the broader accumulation process and the superstructures that rely on it'. Others argue that women's work has always been 'an important source for the primary accumulation of capital' (Broad, 2000, p. 34; also Mies, 1998). This links to a variety of 'social' problems when women are over-burdened and financial crises occur.

Fourth, the economic and social costs of financial crises, like those of SAPs, are disproportionately borne by women and the poor. These costs include: loss of job security and earning capacity in precarious forms of employment; deteriorating life conditions as vulnerable populations pursue survival strategies; more work hours for women as they 'cushion' the impact of household income loss; decreased participation of girls in education and degraded health conditions for women; increased child labor and illicit informal activities; and increased acts of violence against women. ${ }^{20}$ These costs not only disproportionately hurt women in the immediacy and aftermath of crises, but have important long-term effects. On the one hand, girls and women are less able to participate as full members of society, have fewer skills required for safe and secure income generation, and the intensification of women's work with fewer resources imperils social reproduction more generally. On the other hand, entire societies are affected as deteriorating conditions of social reproduction, health, and education have long-term consequences for collective well-being and sustainable development.

Finally, women's reproductive labor has historically been a principal source of human or social capital: 'the knowledge, skills and other attributes relevant to working capabilities' (Gardiner, 1992, 64; also Cloud and Garrett, 1997). This capital assumes strategic importance in the new economy of information and services. As an investment made in the family/household sector and a decisive component of labor and formal production processes, social capital constitutively links all three of the economies. Differential access to and development of social capital also poses continuing problems of inequality and injustice as features of globalizations.

This essay has neglected many important aspects of global processes, not least multiple forms of agency and practices of resistance. These are vital aspects of mapping power, but I have focused instead on presenting a coherent (though not homogeneous or totalizing) picture of globalizations through a focus on economic restructuring. This permitted me to introduce-and I hope demonstrate the value of - a relational analytical framing that moves beyond dominant orientations. The latter are inadequate from the more familiar (if marginalized) vantage points of feminists seeking attention to social reproduction and non-waged labor and Marxists seeking attention to uneven development and relentless exploitation. They are also and particularly inadequate from the less familiar vantage point of postmodernists seeking attention to signs, representations, culture and 'the virtual'. As contributions to our study of globalizations, the RPV framing and triad analytics offer more relational and more critical understanding, in the hope of encouraging more effective resistance to asymmetries of power.

\section{Notes}

1 On the need for more complex, cross-disciplinary analyses see, for example, Palan and Gills (1994), Germain (1997), Herod et al. (1998) and Nagar et al. (2002).

2 My three economies are understood in a Foucauldian sense: as mutually constituted (therefore coexisting and interactive) systemic sites through and across which power operates. These sites include socio-cultural processes of self-formation and cultural socialization that underpin identities and their political implications. The subjective, conceptual and cultural dimensions of these sites are understood as inextricable from (mutually constituted by) material conditions, social practices and institutional structures. Thus, my alternative framing 
enables us to move beyond disciplinary boundaries and to map identities and culture in relation to conventional material and 'structural' phenomena.

3 These claims are elaborated in Peterson (1992, 2003, Chap. 2); see also Amin and Palan (2001), Barker and Kuiper (2003), Gibson-Graham (1996), Hewitson (1999), Chowdhry and Nair (2002) and Mohanty (2003).

4 I understand technologies not deterministically but as historically contingent, socially embedded constructions. On technologies and social relations see, for example, Cockburn and Ormrod (1993), Deibert (1997), May (2002), Current Sociology (2002) and Kofman and Youngs (2003).

5 Rather than costs of importing foreign capital goods being paid for in part by raw materials exports to developed economies, developing countries face a cumulative decline in prices of '50\% over the last 25 years' (UNDP, 1997, p. 9), with decreases continuing into 2003 (UN, 2003).

6 Downgrading is also due to a shift in investment strategies treated in the VE: briefly, in so far as telecommunications and financial markets are perceived to be the leading sectors of the economy, investment is drawn away from traditional manufacturing in favor of these higher profit sectors.

7 This observation links the PE and the virtual economy (VE), even as the phenomenal growth in informal sector activities-which tend to be service oriented-links the PE and the reproductive economy (RE).

8 The ILO's World Employment Report documents and summarizes these trends: high levels of unemployment in most parts of the world, with nearly one-third of the world's labor force unemployed or underemployed, and shifting labor markets shaped by the skills sought: on the rise for skilled labor (professionals and technicians) worldwide; low or even negative for production-related workers (skilled manual and craft workers, as well as unskilled or semi-skilled workers) worldwide, with the exception of growth in the area of unskilled sales and services (reflecting the shift toward services and polarization in service sector jobs). These trends reveal the importance of skills, therefore training, for determining individual employability and national competitiveness (ILO/WER, 1998).

9 See for example the discussions in Bakker (1988, 1994b), Standing (1999), Cagatay and Ozler (1995), Sassen (1998), DAW (1999), World Development (1995, 2000), Castells (1997, pp. 168-175); Wichterich (2000, Chap. 1) and Rai (2002). Women are not passive victims regarding work; rather, they undertake a variety of resistance activities (Young, 2001, p. 46; Pena, 1995) and control of economic resources tends to empower women (Benería and Stimpson, 1987; Blumberg, 1991; Safa, 1995). On women resisting globalizations, see Rowbotham and Mitter (1994), Grewal and Kaplan (1994), Rowbotham and Linkogle (2001).

10 On the politics of identity, place, and globalization see, for example, King (1991), Keith and Pile (1993), Friedman (1994), Brah (1996), Castells (1997) and Massey (1999).

11 On the historical privileging of production over reproduction, with structural implications for gender and related hierarchies, see, for example, Clark and Lange (1979), Laclau and Mouffe (1985) and Peterson (1988).

12 Anker (1987, p. vi) notes that 40 studies of non-European economies 'provide irrefutable evidence on the importance and value of unpaid domestic and household work... [indicating] that national income estimates would be increased by somewhere between 25 and 50 per cent if the economic value of unpaid household activities were taken into account'. See also Waring (1988), Cloud and Garrett (1997), UN/Women (1995, 2000) on valuing women's work in national accounts.

13 The World Bank (2000, p. 39) estimates remittances total about $\$ 75$ billion yearly.

14 This growth has tremendous but relatively understudied implications. Issues include white collar crime, shady financial trading, money laundering, racialized dimensions of incarceration and trafficking in drugs, arms, nuclear materials and the bodies of sex workers and illegal migrants.

15 The phenomenal and unanticipated growth of informal activities has spurred a wide-ranging literature. For example, Yale Law Journal (1994), International Journal of Urban and Regional Research (1994), Lippert and Walker (1997), Staudt (1998), Journal of International Affairs (2000), Schneider and Enste (2000) and Benería (2003).

16 Risks are increased by deregulation and liberalization that effectively 'encourage' taking greater chances in pursuit of higher returns. Rashness is also facilitated by the absence of effective reserve requirements, the spiral of innovative financial instruments, the mentality of short-termism, the lure of 'managing' risk through derivatives and hedge-funds, and the non-transparency of financial transactions. Critics argue that prevailing economic theories fail either adequately to analyze the risk-prone tendencies of financial liberalization (e.g. Bhagwati, 1998; Soros, 1998; Stiglitz, 2002) or take seriously who pays for these risks when crises ensue (e.g. Harvey, 1982; Gill, 1997a; Aslanbegui and Summerfeld, 2000, 2001).

17 Consider, for example, these characteristics of the informational economy: a self-transforming feedback loop between knowledge and its 'use'; the imperative of accelerating innovation; the defiance of exclusive possession; a capacity to increase in value through use; and an intrinsic dissolution of cultural-economic distinctions. 


\section{V. S. Peterson}

18 For example, consumerism's commodification of culture has effects worldwide on how people think (due to the global, though always locally mediated, exposure to advertising and marketing messages), what resources they have (due to naturalizing the ideology of elite consumption), and what work they do (due to production processes driven by northern consumption).

19 On gendering macro-economic policy in both North and South, see especially Bakker (1994a); also World Development (1995, 2000), Elson (2000), Aslanbeigui and Summerfield (2000, 2001), van Staveren (2002). On how masculinism shapes identities, practices and outcomes of financial markets, see McDowell (1997) and Mayhall (2002).

20 These claims are variously documented in Aslanbegui and Summerfield (2000, 2001), Lim (2000), Truong (2000), van Staveren (2002) and World Development (2000).

\section{References}

Amin, A. (1994) Post-Fordism: models, fantasies and phantoms of transition, pp. 1-39 in Amin, A. (ed.) Post-Fordism: A Reader (Oxford: Blackwell).

Amin, A. \& Palan, R. (2001) Towards a non-rationalist international political economy, Review of International Political Economy, 8(4), pp. 559-577.

Anker, R. (1987) Preface, pp. v-vi in Goldschmidt-Clermont, L. Economic Evaluations of Unpaid Household Work: Africa, Asia, Latin America and Oceania (Geneva: ILO).

Aslanbeigui, N. \& Summerfield, G. (2000) The Asian crisis, gender, and the international financial architecture, Feminist Economics, 6(3), pp. 81-104.

Aslanbeigui, N. \& Summerfield, G. (2001) Risk, gender and the international financial architecture, International Journal of Politics, Culture and Society. 15(1).

Bakker, I. (1988) Women's employment in comparative perspective, pp. 7-44 in Jenson, J., Hagen, E. \& Reddy, C. (eds) Feminization of the Labor Force: Paradoxes and Promises (New York: Oxford University Press).

Bakker, I. (1994a) Introduction, pp. 1-29 in Bakker, I. (ed.) The Strategic Silence: Gender and Economic Policy (London: Zed Books).

Bakker, I. (ed.) (1994b) The Strategic Silence: Gender and Economic Policy (London: Zed Books).

Barker, D. K. \& Kuiper, E. (eds) (2003) Toward a Feminist Philosophy of Economics (London \& New York: Routledge). Benería, L. (2003) Gender, Development and Globalization: Economics as if People Mattered (New York: Routledge).

Benería, L. \& Stimpson, C. (eds) (1987) Women, Households and the Economy (New Brunswick, NJ: Rutgers University Press).

Berik, G. (1999) Globalization, pp. 402-411 in Peterson, J. \& Lewis, M. (eds) The Elgar Companion to Feminist Economics (Cheltenham: Edward Elgar).

Bhagwati, J. (1998) The capital myth: the difference between trade in widgets and dollars, Foreign Affairs, May.

Blumberg, R. L. (ed.) (1991) Gender, Family, and Economy (Newbury Park: Sage).

Brah, A. (1996) Cartographies of Diaspora: Contested Identities (London: Routledge).

Cagatay, N. \& Ozler, S. (1995) Feminization of the labor force, World Development 23(11), pp. 1883-1894.

Castells, M. (1997) The Information Age, Vol. 2. The Power of Identity. (Oxford: Blackwell).

Castells, M. (2000) The Information Age, Vol. 1. The Rise of the Network Society. 2nd edn (Oxford: Blackwell).

Castells, M. \& Portes, A. (1989) World underneath: the origins, dynamics, and effects of the informal economy, pp. 11-37 in Portes, A., Castells, M. \& Benton, L. A. (eds) The Informal Economy: Studies in Advanced and Less Developed Countries (Baltimore: Johns Hopkins University Press).

Chant, S. (1997) Women-Headed Households: Diversity and Dynamics in the Developing World (New York: St. Martin's Press).

Chowdhry, G. \& Nair, S. (eds) (2002) Power, Postcolonialism and International Relations: Reading Race, Gender and Class (New York: Routledge).

Clark, L. M. G. \& Lange, L. (eds) (1979) The Sexism of Social and Political Theory: Women and Reproduction from Plato to Nietzsche (Toronto: University of Toronto Press).

Cloud, K. \& Nancy Garrett (1997) A modest proposal for inclusion of women's household human capital production in analysis of structural transformation. Feminist Economics, 3(1), pp. 151-177.

Cockburn, C. \& Ormrod, S. (1993) Gender and Technology in the Making (London: Sage).

Current Sociology (2002) Special Issue: Information and Communication Technologies, 50(3) (May).

DAW/Division for the Advancement of Women, United Nations (1999) World Survey on the Role of Women in Development (New York: United Nations). 
Deibert, R. J. (1997) Parchment, Printing and Hypermedia: Communication in World Order Transformation (New York: Columbia University Press).

Dickinson, T. D. \& Schaeffer, R. K. (2001) Fast Forward: Work, Gender, and Protest in a Changing World (Lanham: Rowman \& Littlefield).

Drucker, P. F. (1997) The global economy and the nation-state, Foreign Affairs, 76(5), pp. 159-171.

Dunning, J. H. (2000) Regions, globalization, and the knowledge economy: the issues stated, pp. 7-41 in Dunning, J. H. (ed.) Regions, Globalization, and the Knowledge-Based Economy (Oxford: Oxford University Press).

Elson, D. (2000) Gender at the macroeconomic level, pp. 77-97 in Cook, J., Roberts, J. \& Waylen, G. (eds) Towards a Gendered Political Economy (London: Macmillan).

Friedman, J. (1994) Cultural Identity and Global Process (London: Sage).

Gardiner, J. (2000) Gender and family in the formation of human capital, pp. 61-75 in Cook, J., Roberts, J. \& Waylen, G. (eds) Towards a Gendered Political Economy (London: Macmillan).

Germain, R. D. (1997) The International Organization of Credit, States and Global Finance in the World-Economy (Cambridge: Cambridge University Press).

Gibson-Graham, J. K. (1996) The End of Capitalism (as we knew it): A Feminist Critique of Political Economy (Cambridge, MA: Blackwell).

Gill, S. (1997a) Finance, production and panopticism, pp. 51-75 in Gill, S. (ed.) Globalization, Democratization and Multilateralism (London: Macmillan/UNU Press).

Gill, S. (ed.) (1997b) Globalization, Democratization and Multilateralism (London: Macmillan).

Grewal, I. \& Kaplan, C. (1994) Introduction, pp. 1-33 in Grewal, I. \& Kaplan, C. (eds) Scattered Hegemonies: Postmodernity and Transnational Feminist Practices (Minneapolis: University of Minnesota Press).

Grown, C., Elson, D. \& Cagatay, N. (2000) Introduction, World Development, 28(7), 1145-1156.

Harvey, D. (1982) The Limits to Capital (Oxford: Blackwell).

Herod, A., Tuathail, G. \& Roberts, S. (eds) (1998) Unruly World: Globalization, Governance and Geography (London: Routledge).

Hewitson, G. J. (1999) Feminist Economics: Interrogating the Masculinity of Rational Economic Man (Cheltenham: Edward Elgar).

Hoogvelt, A. (2001) Globalization and the Postcolonial World: The New Political Economy of Development, 2nd edn (Baltimore, MD: The Johns Hopkins University Press).

ILO/WER (World Employment Report) (1998) Press Kit on global employment prospects. < http://www.ilo.org/public/ english/bureau/inf/pkits/wer98/wer98ch1.htm>. [Accessed 2 June 2002].

International Journal of Urban and Regional Research (1994) Special Issue: Informal Economy and Family Strategies, 18(March).

Journal of International Affairs (2000) Special Issue: The Shadow Economy, 53(2), (Spring).

Keith, M. \& Pile, S. (eds) (1993) Place and the Politics of Identity (London: Routledge).

Kelly, R. M., Bayes, J. H., Hawkesworth, M. E. \& Young, B. (eds) (2001) Gender, Globalization, \& Democratization (Lanham, MD: Rowman \& Lttlefield).

King, A. D. (ed.) (1991) Culture, Globalization and the World System: Contemporary Conditions for the Representation of Identity (London: Macmillan).

Kofman, E. \& Youngs, G. (eds) (2003) Globalization: Theory and Practice, 2nd edn (London \& New York: Continuum).

Laclau, E. \& Mouffe, C. (1985) Hegemony and the Socialist Strategy: Toward a Radical Democratic Politics (London: Verso).

Lash, S. \& Urry, J. (1994) Economies of Signs and Space (London: Sage).

Lim, J. Y. (2000) The effects of the East Asian crisis on the employment of women and men: the Philippine case, World Development, 28(7), pp. 1285-1306.

Lippert, O. \& Walker, M. (eds) (1997) The Underground Economy: Global Evidence of its Size and Impact (Vancouver: The Fraser Institute).

McDowell, L. (1997) Capital Culture: Gender at Work in the City (Oxford: Blackwell).

Marchand, M. H. \& Sisson Runyan, A. (eds) (2000) Gender and Global Restructuring: Sightings, Sites and Resistances (London: Routledge).

Massey, D. R. et al. (1999) Worlds in Motion: Understanding International Migration at the End of the Millennium (Oxford: Clarendon Press).

May, C. (2002) The Information Society: A Skeptical View (Cambridge: Polity).

Mayhall, S. (2002) 'Riding the Bull/Wrestling the Bear. Dissertation (Toronto: York University).

Mies, M. (1998) Patriarchy and Accumulation on a World Scale: Women and the International Division of Labour, new edn with preface (London: Zed Books). 


\section{V. S. Peterson}

Mittelman, J. H. (ed.) (1996) Globalization: Critical Reflections (Boulder, CO: Westview).

Mohanty, C. T. (2003) Feminism Without Borders: Decolonizing Theory, Practicing Solidarity (Durham: Duke University Press).

Nagar, R., Lawson, V., McDowell, L. \& Hanson, S. (2002) Locating globalization: feminist (re)readings of the subjects and spacs of globalization, Economic Geography, 78(3), pp. 257-284.

Palan, R. \& Gills, B. (eds) (1994) Transcending the State-Global Divide: A Neostructuralist Agenda in International Relations (Boulder, CO: Lynne Rienner).

Pena, D. (1995) Terror of the Machine: Technology, Work, Gender, and Ecology (Austin: University of Texas Press).

Peterson, V. S. (1988) An archeology of domination: historicizing gender and class in early Western state formation,. PhD. diss., The American University.

Peterson, V. S. (1992) Transgressing boundaries: theories of knowledge, gender, and international relations, Millennium, 21(2), pp. 183-206.

Peterson, V. S. (2003) A Critical Rewriting of Global Political Economy: Integrating Reproductive, Productive and Virtual Economies (London: Routledge).

Rai, S. M. (2002) Gender and the Political Economy of Development (Cambridge: Polity).

Rowbotham, S. \& Linkogle, S. (eds) (2001) Women Resist Globalization: Mobilizing for Livelihood and Rights (London $\&$ New York: Zed Books).

Rowbotham, S. \& Mitter, S. (eds) (1994) Dignity and Daily Bread: New Forms of Economic Organization in the Third World and the First (London: Routledge).

Safa, H. (1995) The Myth of the Male Breadwinner: Women and Industrialization in the Caribbean (Boulder, CO: Westview Press).

Sassen, S. (1998) Globalization and its Discontents (New York: New Press).

Sassen, S. (2000) Women's burden: counter-geographies of globalization and the feminization of survival, Journal of International Affairs, 53(2), pp. 503-524.

Schneider, F. \& Enste, D. H. (2000) Shadow economies: size, causes, and consequences, Journal of Economic Literature, XXXVIII(March), pp. 77-114.

Sivard, R. L. (1995) Women ... A World Survey, 2nd edn (Washington, DC: World Priorities).

Soros, G. (1998) The Crisis of Global Capitalism (New York: Public Affairs).

Standing, G. (1999) Global feminization through flexible labor: a theme revisited, World Development, 27(3), pp. 583-602.

Staudt, K. (1998) Free Trade? Informal Economies and at the U.S.-Mexico Border (Philadelphia: Temple University Press).

Stiglitz, J. E. (2002) Globalization and Its Discontents (New York: W. W. Norton).

Thrift, N. (1996) Spatial Formations (London: Sage).

Tomlinson, J. (1999) Globalization and Culture (Chicago: University of Chicago Press).

Truong, T.-D. (2000) A feminist perspective on the Asia miracle and crisis, Journal of Human Development, 1(1), pp. 159-164.

United Nations (2001) World Economic and Social Survey 2001 (New York: United Nations).

United Nations (2002) World Economic Situation and Prospects 2002 (New York: United Nations).

United Nations (2003) World Economic Situation and Prospects 2003 (New York: United Nations).

United Nations Development Program (1997) Human Development Report 1997 (New York: Oxford University Press). United Nations Development Program (1999) Human Development Report 1999 (New York: Oxford University Press). United Nations/Women (1995) The World's Women 1995: Trends and Statistics (New York: United Nations).

United Nations/Women (2000) The World's Women 2000: Trends and Statistics (New York: United Nations).

Urry, J. (1990) The Tourist Gaze (London: Sage).

Van Staveren, I. (2002) Global finance and gender, pp. 228-246 in Scholte, J. A. \& Schnabel, A. (eds) Civil Society and Global Finance (London: Routledge).

Waring, M. (1988) If Women Counted: A New Feminist Economics (San Francisco: Harper).

Wichterich, C. (2000) The Globalized Woman: Reports from a Future of Inequality (London: Zed Books).

World Bank (2000) World Development Report 1999/2000: Entering the 21st Century (Oxford: Oxford University Press).

World Development (1995) Special Issue: Gender, Adjustment and Macroeconomics, 23(11).

World Development (2000) Special Issue: Growth, Trade, Finance, and Gender Inequality, 28(7).

Yale Law Journal (1994) Symposium: The Informal Economy, 103(8).

Young, B. (2001) Globalization and gender: a European perspective, pp. 27-47 in Kelly, R. M., Bayes, J. H., Hawkesworth, M. E. \& Young, B. (eds) Gender, Globalization, \& Democratization (Lanham: Rowman \& Littlefield). 
V. Spike Peterson is a Professor in the Department of Political Science at the University of Arizona, with courtesy appointments in Women's Studies, Comparative Cultural and Literary Studies, and International Studies. Her most recent book is A Critical Rewriting of Global Political Economy (2003). She contributed to and edited Gendered States: Feminist (Re) Visions of International Relations Theory (1992) and with Anne Sission Runyan co-authored Global Gender Issues (1999/1993). She has enjoyed Visiting Research Fellowships at Göteburg University, University of Bristol, the Australian National University, and the University of Southern California. 


\section{$\Longrightarrow$ Taylor \& Francis \\ Taylor \& Francis Group}

\section{TO: CORRESPONDING AUTHOR}

\section{AUTHOR QUERIES - TO BE ANSWERED BY THE AUTHOR}

The following queries have arisen during the typesetting of your manuscript. Please answer the queries

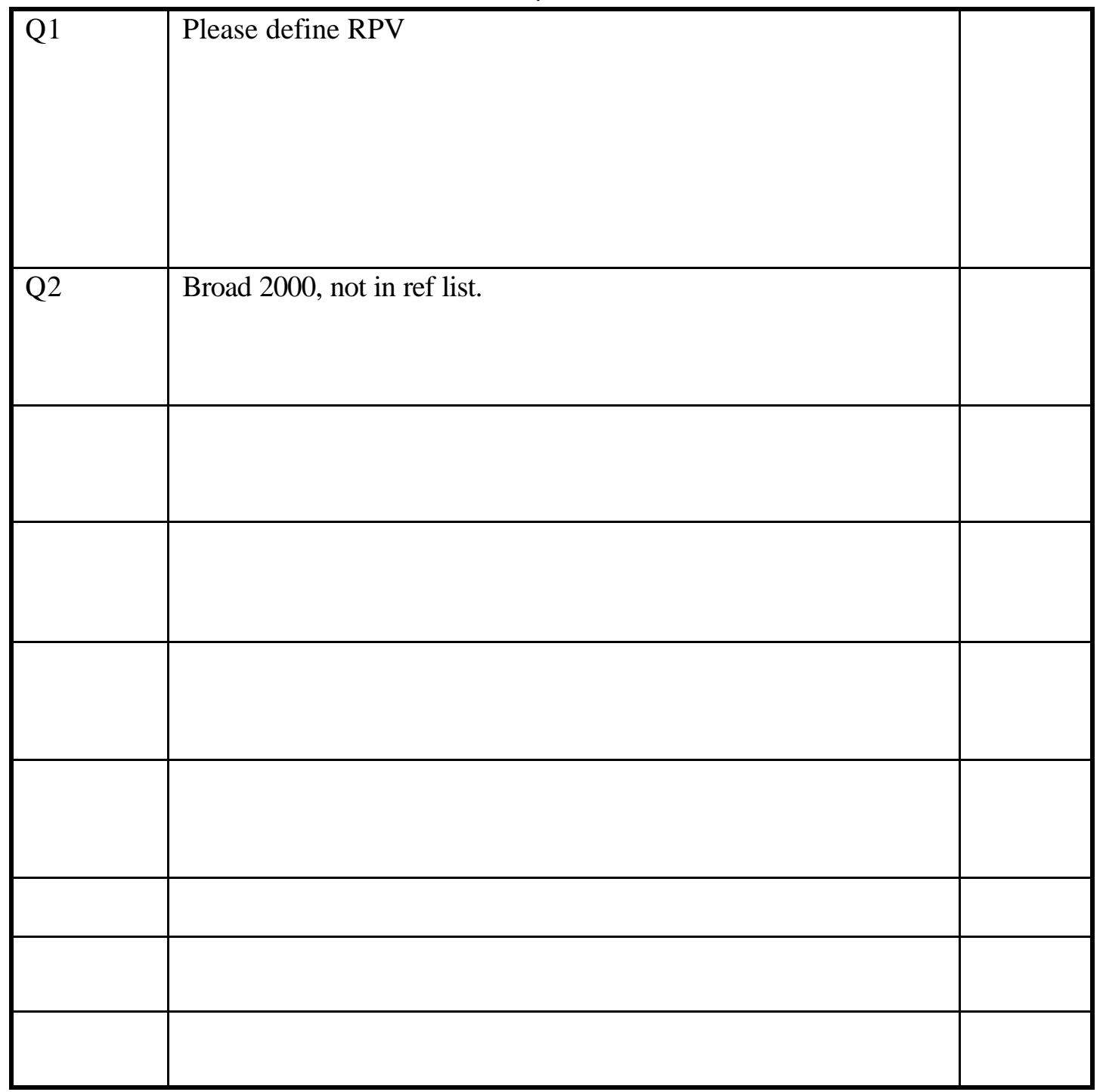

Production Editorial Department, Taylor \& Francis Ltd.

4 Park Square, Milton Park, Abingdon OX14 4RN

Telephone: +44 (0) 1235828600

Facsimile: +44 (0) 1235829000 